\title{
I. VERBONDE LITERATUUR IN AFRIKAANS
}

Litterature engagée is ' $n$ veel voorkomende frase in geskrifte en gesprekke oor die letterkunde van ons tyd. Ons vertaal hierdie Franse sinsnede gewoonlik as "verbonde literatuur", soms ook as "betrokke letterkunde". Daarmee benoem 'n mens dan 'n spesifieke soort woordkuns, te wete dié wat heel opvallend na onderwerp of tema bemoeienis maak met die politieke, sosiale, ekonomiese toestande, gewoonlik wantoestande, van sekere groepe of klasse mense of hele bevolkingsdele. Dit gaan om die welsyn, of gebrek daaraan, van 'n gemeenskap, dus 'n kollektiewe ideaal of belang, al werk die literatuur by voorkeur uiteraard met die beelding van die konkrete enkeling. Daardie individu in die verbonde literatuur is altyd in ' $n$ mindere of meerdere mate simbool van 'n groep, 'n klas, 'n volk.

Litterature engagée het 'n reformasie in die oog, of selfs rewolusie. Maar altyd wil dit 'n verandering probeer bewerkstellig, of minstens daartoe meewerk. So 'n verbonde skrywer besef maar al te goed dat hoe holrug gery die spreekwoord: die pen is magtiger as die swaard, ook al mag wees, die waarheid daarvan nog nie uitgedien is nie. Veral nie in die kommunikasieparadys wat die moderne wêreld is nie. Daar word wel soms hooghartig van die inflasie van die woord gepraat, maar nog nooit in die geskiedenis van die mens is soveel woorde met soveel aandag deur soveel mense gelees en aangehoor as juis vandag nie. Hoe seer die woord ook deur valsaards gedevalueer word, is daar altyd genoeg kundige, bewoë, oortuigde en oortuigende hanteerders daarvan om dit telkens verrassend te revalueer. Per slot van sake is die woord en alles wat daarin uitgedruk kan word, juis die mens se unieke kenmerk en hoogste besit. Dit weet die verbonde skrywer, en daarop steun die litterature engagée.

Dis ' $n$ heel resente frase hierdie: litterature engagée, verbonde literatuur, literêre engagement, verbondenheid. Jy kry dit byvoorbeeld selfs nie in die jongste uitgawe van Shipley se gesaghebbende Dictionary of World Literature nie, of in Grové se Letterkundige Sakwoordeboek nie. Maar al is die term jonk, is die verskynsel wat dit benoem, so oud as die berge. Die letterkunde het hom nog altyd bemoei met die condition humaine, sy dit dan nie so aktivisties soos 'n be- 
paalde soort geskrif van die moderne tyd nie. Maar 'n mens sou wel elemente van sosiale hervormingsdrang in die letterkunde van elke ontwikkelde volk van alle tye aantref, sy dit die ou Grieke, die Romeine, die Jode, die Wes-Europese volke.

Dis nie hier die plek om op die funksie, aard en verskeidenheid van die literatuur in te gaan nie - nie eens dié van ons stamlande of kulturele leenhere uit die Oudheid nie. Ek wil net op een saak wys, en dit is dat met die koms van die Renaissance die literatuur begin het om sy gemeenskapskarakter te verloor. Daar is twee hoofredes voor.

Eerstens het die blote tegniese uitvinding, die boekdrukkuns, die letterkunde privaat gemaak. Gesproke woordkuns is openbaar, van 'n gehoor afhanklik; leesliteratuur is iets vir die enkeling en die afsondering. Tweedens het die Renaissance 'n herwaardering van die enkeling gebring in die gees van die mensheid, en so het die letterkunde hom dan ook al hoe meer gaan toelê op die individu: die beelding van sy innerlike, sy ervaringe, gewaarwordinge, strewes. Hierdie individualisme bereik 'n hoogtepunt tydens die negentiende eeuse Europese Romantiek. Die Afrikaanse ekwivalent daarvan is die vroeë kuns van ons Dertigers. Voor die tyd het ons hoofsaaklik gemeenskapskuns gehad, volkskuns, soos dit heet. En dit is eers Opperman en die ander Veertigers wat ' $n$ einde gemaak het aan die Romantiek en die hiperindividualisme van Dertig. Nie dat hulle weer so gemoedelik as die Patriotters of die Driemanskap geskryf het nie - nee, hulle het die idioom van die moderne tyd benut en uitgebou, maar die Veertigerdigkuns het 'n ryke tematiek gebring, onder meer 'n sosiale deernis met die wanaangepaste, swoegende, verstedelikte Afrikaner wat mentaal nog landelike mens is. Dit is 'n waar woord wat die Vyftiger Peter Blum, nog 'n digter met 'n sterk ontwikkelde maatskaplike sintuig en gewete, van Opperman geskryf het:

„Eers die bonkige Zoeloelander met skerper beeldspraak, Heilsame aardsheid en emosies minder krampagtig,

Het Afrikaanse verse vir my weer skryfbaar laat word."

Tot die jare Sestig was die Afrikaanse digkuns op die voorpunt van ons literêre ontwikkeling en die leesbaarste barometer van die Afrikaner se geestelike aktiwiteit, wat op sy beurt weer wortel in die volle bestaan. Dis die poësie wat toon hoe die literatuur na Dertig wegneig van die middelpuntsoe- 
kende, die oog weer na buite rig. Maar hierdie sosiale funksie kan veel beter verrig word deur ander genres as die digkuns, want dié het wesenlik leespoësie geword, konsentrasiewerk in die enigheid vir die ingewyde. Die roman daarenteen het nog altyd, veral op grond van sy storie-element, 'n populêrder karakter behou. Maar dit is eintlik die drama wat niks anders kan wees as gemeenskapskuns nie, wat die ideale voertuig is vir gedagtes en ideale van hervorming. Dit is die litterature engagée by uitnemendheid. In die Sestigerjare kry ons eers die opbloei van die Afrikaanse romankuns, en dit lyk of die drama sy vere regskud vir 'n kemphaangeveg met versteende gedagtes, vormverstarring, taboes en maatskaplike opvattings en toestande.

Dat die Afrikaanse literatuur méér wil wees as verstrooiing, vermaak, maanskyn en rose, bevreem 'n mens nie. Die letterkunde is ' $n$ produk van die gees van die mens, en die Afrikaanse mens was nog altyd 'n stryder, 'n dinamiese wese, erfgenaam van die Renaissance èn die Hervorming. Ons literatuur is 'n kind van die storm van sy wieg af, was eintlik nog altyd engagée.

So is die heel eerste geskrif in Afrikaans wat tot ons literatuur gereken word, te wete Klaas Waarzegger se Zamenspraak, gebore uit 'n politieke stryd en die Afrikaner se betrokkenheid by landsake. Politiek en maatskaplike onreg en verguising is dominante in die hele Patriotbeweging en letterkunde. Die stemvurk van die letterkunde van die Tweede Beweging, Winternag, is meer as 'n natuurvers: dis die smartlike versugting van 'n verskroeide aarde en 'n verslae en oorwonne volk. Hierdie volk herower sy land in die natuurverse van Leipoldt, Totius en Celliers, kla oor die onreg, ween oor die smart, spoor aan tot die stryd. Hierdie spoorslag bereik sy klimaks in Van Wyk Louw se Gedagtes, Liedere en Gebede van 'n Soldaat (DIE HALWE KRING). Daar lees ons verse soos die volgende:

„en as my hande wurge, o God, rondom ' $n$ keel een dag, wees $\mathrm{U}$ die bloed, wees $\mathrm{U}$ die spier, wees U my greep se krag."

Verder van "die dag-helder vreug van ons opstand teen die kwaad", „ons wil moet blink wees", ,júlle is die oorheersers", 
en van die wete:

„dat ons nie kon gebuig word

soos húl geweld dit wou,

en dat ons hoog kon lewe

net aan ons bloed getrou."

Dit is nie aangename woorde in die ore van die "verdrukkers" nie, maar dan: verbonde literatuur het nog altyd namens die underdog gepraat en vir sy belange gestry. Die bydrae van die literatuur om die Afrikaner weerbaar te maak en hom sy regmatige plek in sy geboorteland te gee, is 'n nog onontgonne studieterrein. Maar net dit: sonder ons literatuur is dit ondenkbaar dat die Afrikaner geword het wat hy is in ons land. Dit is seker die eerste en kenbaarste bydrae tot sy opkoms of herstel. Voorbeelde uit ons poësie, prosa en drama lê vir die gryp, van die ironiese Vooruitgang van Hoogenhout tot Opperman se Joernaal van Jorik.

Met die Afrikaner in 'n heersersposisie in die land, veral op politieke gebied vanwaar hy sy ideë implementeer, het die versetliteratuur as 'n stroming in ons geesteslewe nie sy wesensaard ingeboet nie. Wel in sommige kringe sy populariteit. Dat ' $n$ mens in Afrikaans kan skryf teen die Afrikaner en sy siening en hantering van sake, lyk vreemd, is in die lig van die verlede en selfs die huidige situasie ontstellend, sweem vir baie selfs na moedswilligheid indien nie na 'n soort verraad nie. Daarom stuit dié soort woordkuns op ongeduld, meer nog: op veroordeling. Want, so word daar geredeneer: hierdie skrywers van versetliteratuur is op die minste onverantwoordelik.

En met hierdie deesdae so kwistig rondgestrooide woord „verantwoordelikheid" is ons midde in die spanninge van die huidige literêre situasie. Verantwoordelik teenoor wie? vra die skrywer: die waarheid, die gevestigde leuen, die oorgelewerde onregte, die staat, God? En wie kan beslis wat is waarheid, wat is reg? Diegene wat hulle aanmatig om te sê ander weet nie waarom dit gaan nie, dat sulke ontevredenes misleide en verblinde enkelinge, gefrustreerde uitwasse is - sulke hubris is dwaas en katastrofaal.

Literêr is byvoorbeeld die saak van politieke verantwoordelikheid minstens deur Leipoldt se Oom Gert vertel en Bart $\mathrm{Nel}$ van J van Melle uitgemaak. Hier is nou twee skrywers wat hulle diep verbonde aan die Afrikaner en betrokke by die 
toestande gevoel het: by Leipoldt 'n hartstogtelike verset teen onreg, by Van Melle 'n ewewigtiger, objektiewer maar nietemin diep bewoë bewussyn van die Afrikanerstryd. In Leipoldt se dramatiese monoloog is Oom Gert, kragtens sy eie belydenis, tegnies 'n rebel. Want hy, as Kolonialer, oortree die krygswet deur die twee jongmanne aan perde, proviand en raad te help om by die Boerekommando aan te sluit. Hy is verder bewus van die risiko, die lewensgevaar, die dreigende tragedie, maar Oom Gert beroep hom op sy verbondenheid aan sy volk. Dit verg sy hoogste trou.

Bart Nel, in die gelyknamige roman van $\mathbf{J}$ van Melle, is in feite 'n rebel, en wel in die Gewapende Verset van 1914. Hy neem doelbewus die wapen op teen die regering van Botha en Smuts, tree selfs op as offisier. Hy offer huweliksgeluk op vir hierdie ideaal, want sy vrou veroordeel sy optrede. Hy raak stoflik geruïneer omdat hy veel skuld aangaan om sy manskappe toe te rus. Uiteindelik verloor hy alles: hy is verouder, verlate. En tog beeld die skrywer hom as 'n oorwinnaar, want hy behou sy siel. Hy bly enduit getrou aan sy diepste wese, aan sy beginsels, en dié is dat daar 'n Hoër Gesag is as die landsregering. Volgens Bart Nel se oortuiging handel Botha en Smuts verkeerd om die oorlewendes van die konsentrasiekampe as soldate van Engeland te gebruik teen DuitsSuidwes-Afrika. Die regering kom die Afrikaner te na, en daarom neem hy die wapen op om die onreg te herstel. Bart Nel staan in die sentrum van die verhaal, geniet die leser se simpatie, en nooit word sy motiewe of optrede in die roman veroordeel nie. Sy vrou en politieke teenstanders wys hom op die tekortkominge in sy siening van sake, die verkeerdheid van sy optrede, maar die roman self veroordeel hom nie. Inteendeel, hy is 'n held, wel tragies, maar nietemin 'n heldefiguur.

Dit is twee voorbeelde van politieke betrokkenheid by skrywers uit 'n vroeër periode. Ander aspekte van "die eeu van onreg" kom natuurlik eweneens aan bod: dink maar aan die talle ",armblankeromans", die taal- en kultuurverguising soos 'n mens lees in Joernaal van Jorik:

„Hul pluk my eeufeesbaard en -snorbaard uit, hul klap my woorde terug weer in my mond..."

Al hierdie motiewe in die literatuur is natuurlik neweprodukte van die politieke stryd van die Afrikaner wat sy volle 
neerslag kry in die letterkunde tot 1948 toe die Republiek in beginsel herstel is met die oorwinning van die Nasionale Party in die algemene verkiesing van daardie jaar. Soos hoërop gesê, die volle gamma van die literatuur: poësie, prosa en drama, weerspieël hierdie strewe en stryd: van Klaas Waarzegger se Zamenspraak, oor Catharina die dogter van die Advokaat, Die eselkakebeen, die romans van Jochem van Bruggen, D F Malherbe, C M van den Heever, die poësie van die Driemanskap, Van Wyk Louw se "nasionale" verse, tot by Opperman en Blum.

In 'n gedig soos Nuus uit die binneland beklemtoon Blum dat ons die volle konsekwensies van die „vasteland waarop ons boer", moet aanvaar. Daarom satiriseer hy ook die „Rooinekke op Hermanus" meedoënloos, daardie pensioentrekkers op vergane roem wat hulle gesig afwend van hierdie harde land en oor die see uitstaar. Maar by Blum is die satire nog nie venynig nie, is die spot dikwels goedig, soos in sy Kaapse sonnette waarin hy heelwat heilige koeie van die Afrikaner hekel, op sosiale en rasse-misstande wys. Dink maar in hierdie verband ook aan Opperman se gediggie Kiets uit die aktualiteitsbundel BLOM EN BAAIERD:

In die donker krotte van Distrik Ses

maak ons duisendes saam met die muise nes,

en die rykes hang in glas en lig

in die huise hoog teen Oranjezicht,

maar dis sus of so vir die skollie met die mes.

Die jaar 1948 bring dus 'n kentering, nie net politiek nie, maar ook in die gerigtheid van kritiek in die literatuur. Van dié tyd af is die Afrikaner die maghebber, en as sodanig moet hy ook die verantwoordelikheid, en kritiek, aanvaar. Bowendien is dit 'n wêreldwye verskynsel in die literatuur van na die Tweede Wêreldoorlog dat die letterkunde hom doelbewus wil bevry uit sy "ivore toring" en midde in die volle werklikheid wil staan, ook die barre en ongure werklikheid. Met ander woorde: die private emosies van die woordkunstenaar is nie so belangrik nie, die "mooi woord" van ' $n$ vroeëre tyd (by ons: Dertig) is 'n anachronisme. Die tyd van individualisme en estetisisme is verby. Literatuur wat verdoof, ontvlug, die self vertroetel, die mooie en net die mooie voorhou, is 'n leuen. Eerlikheid en strydbaarheid word die nuwe slag- 
spreuk. Die literatuur moet die volle lewe reflekteer en dien.

Hierdie internasionale tendens sluit aan by die inheemse natuurlike groei en ontwikkeling, en die gesamentlike uitwerking tref ons met die nuwe opbloei van die literatuur, veral die romankuns, in die Sestigerjare. Sestig bring nie net nuwe temas, tegnieke en styl nie. Die groeibodem van al hierdie uiterlikhede is ' $n$ veranderde lewensbeskouing, soos onder meer Bartho Smit die saak beredeneer het in die tydskrif Sestiger. Die vernaamste woordvoerder van Sestig is André P Brink, en hy belig talle aspekte van die nuwe geestesgesteldheid, onder andere die wil van die moderne skrywer om betrokke te wees, deel te hê aan die literêre "engagement".

Sonder om op al die teoretiese aspekte van die uitsprake in te gaan, kan 'n mens net na enkele letterkundige manifestasies van die ,engagement" kyk. Laat ek dadelik sê dat politieke of sosiale betrokkeheid van die skrywer (nog) nie die hoofrigting in ons literatuur verteenwoordig nie, dat dit wel histories aansluit by 'n gevestigde tradisie in ons letterkunde, maar dat die aksente nou feller is, die stem harder, die houding onvergeefliker, die aandrang sterker, die stemming intenser en grimmiger.

So noem Jan Rabie 'n roman van hom: Ons die afgod. Hierdie ons is die blanke in Suid-Afrika, by name die Afrikaner, die Afrikaner wat sy wit vel verafgood en dit die norm van alles maak. Baie jare later skryf Breyten Breytenbach in dieselfde striemende trant:

ek is Germaans

ek is wreed

ek is blank ens

(Please don't feed the animals)

Hierdie bundel OORBLYFSELS bevat meer gedigte wat uitdrukking gee aan die digter se standpunt oor die verhouding wit-swart in hierdie land, soos ook SKRYT fel antagonistiese - verse bevat, om dit nou maar sagkens te stel. Dit is miskien die naaste wat ons aan werklik aktivistiese woordkuns in Afrikaans kom, en nogtans is dit nie van so 'n krasse opswepende, rewolusionêre aard dat dit nie in Suid-Afrika publiseerbaar is nie. En daarby is Breyten se werk van so 'n woordkunstige gehalte (dit wissel natuurlik) dat sy bundels om bloot estetiese redes nog 'n bestaansreg waarborg. Maar ook 
by hom, ten spyte van sy gedwonge ballingskap en sy huwelik wat hom in direkte konfrontasie met die wet en die sosiale status quo in sy vaderland bring, lewensomstandighede wat probleme en veral skrynende verlange meebring, verteenwoordig die strydverse nie die hoofrigting of korpus van sy oeuvre nie. Tereg haal hy aan as motto in sy gedig Septembersee: die ballingskap is ' $n$ moeilike taak. Maar hy is in die eerste plek liefdesdigter, en in hierdie opsig bou hy voort op 'n tradisie van hoë gehalte in Afrikaans en het 'n eie en indrukwekkende bydrae gelewer. Om die taalavontuur van sy beste verse mee te maak is ' $n$ verruklike en verrassende ontdekkingstog, en sy eie belewenis en visie van die verhouding tussen man en vrou is 'n teer, piëteitvolle hooglied.

Nog meer as Breyten ervaar die Afrikaansskrywende Kleurlingdigter en -dramaturg Adam Small die gevolge van die amptelike en nie-amptelike rassebeleid in sy vaderland aan eie lyf. Hy skryf minder militant as Breyten, met sterker religieuse bowe- en ondertone, implementeer meer die humor wat die rouheid versag, maar wat tog ook weer 'n oneindig menslike en dikwels tragiese dimensie aan sy beelding van sake gee. Hierdie rouheid van sy klag en verwyt word verhoog deur die aanwending van die Kaapse Kleurling-patois wat hy tot literêre voertuig verhef en wat sy beste verse en dramas 'n outentisiteit en trefkrag gee wat dit enig in ons letterkunde maak. Sy striemende ironie blyk uit feitlik elke gedig, maar iets soos Second Coming II, waarin die wederkoms van Christus in terme van die aankoms van 'n verhoogkunstenaar gebeeld word wat op die lughawe 'n afsonderlike optrede voor sy Nieblanke ondersteuners beloof, wil die reëlings van mense ernstig kontrasteer met God se bedoeling.

Dit is nie my oogmerk om die onderwerp van literêre engagement met voorbeeld op voorbeeld uit te put nie - eerder om die aard en intensiteit en gehalte daarvan effens toe te lig. Dit is egter opvallend dat kritiek op en veroordeling van maatskaplike en politieke toestande in 'n mindere of meerdere mate by die meeste jonger digters van ons tyd voorkom.* 'n Goeie en ook verteenwoordigende voorbeeld is Fanie

* Vgl my referaat gelewer by die jaarvergadering van die S.A. Akademie vir Wetenskap en Kuns in Julie 1971 te Potchefstroom: Mens en letterkunde in die dekade Sewentig, oorgedruk in DIE MENS EN DIE WERELD Tafelberg-Uitgewers Kaapstad 1972 
Olivier se bundel $O m$ alleen te reis (1973). Naas gedigte wat sintuiglike indrukke as 't ware reisigergewys poëties verwerk, liefdesverse en ook 'n hele afdeling met 'n sterk ironiese maar dan tog speelse karakter, is daar ook enkele gedigte wat duidelik polities betrokke wil wees. Wat nog in die gedig oor die besoek van Breyten en sy vrou Yolande trefsekere spot is, word in die slotgedig, opgedra aan Van Wyk Louw, 'n striemende aanklag teen apartheid. Die gedig praat onder meer van

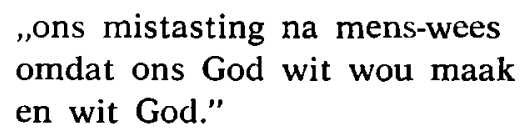

Die "dieper reg" wat uiteindelik sal seëvier, is 'n ironiese toespeling op en verwysing na Van Wyk Louw se koorspel oor die reg van die Afrikanervolk; hier by Olivier beteken dit iets anders:

God sal Sy oordeel oor die trots

die meerderwaardigheid nie altyd uitstel nie:

dít dui die swart gebalde vuis:

want ek glo amper soos jy die dieper

reg sál seëvier soos in die hemel

so ook in hierdie menslike paradys.

Dit is 'n egte politieke engagé-gedig hierdie: hartstogtelik, kruisvarend vir 'n ideaal, eensydig, bewoë. Wat 'n mens ook al van die ideologie en sentiment daarvan mag sê, dit is geinspireerde, treffende en goeie poësie.

By ons is dit hoofsaaklik engagement in 'n politieke sin, en politiek dan soos dit die bevolkingsverhoudingswette en maatreëls aangaan: apartheid. By sommige woordkunstenaars is die reaksie, die afwysing fel, maar altyd bewoë. Daar is ' $n$ ernstige en myns insiens opregte betrokkenheid en bekommernis, hoewel 'n mens natuurlik by alle betogendes 'n sekere eensydigheid en oorbeklemtoning vind. Maar louter propaganda word dit nie - dit bly essensieel woordkuns. Dit is veral die menslike tragiek wat die kunstenaar aangryp, soos Opperman se gedig Draaiboek uit die bundel met die sprekende titel BLOM EN BAAIERD aantoon:

Kiek badkamer, maar swak belig; wys seun wat aan 'n tou verwurg. 
Eine kleine Nachtmusik - verdof

Wissel flitstonele, huis en hof:

„Waarom het hy dié nag hom opgehang?

Was daar miskien 'n nooi in die gedrang?"

„Nee, al was my oudste in sy fleur,

het hy hom aan g'n nôi gesteur."

„Soms raak 'n vader en sy seun oorhoop.

Het dié hom dikwels deurgeloop?"

„Nee, 'n ware aanspraak sonder gier net graag alleen voor die klavier."

„Mevrou, kan u ons waarlik niks vertel?"

„Ag, Edelagbare, dis God se spel!"

"Maar waarom ... waarom so 'n daad verrig?"

„Sy vel was donker, sy broers s'n lig."

Kiek waar vier kinders vroeg opstaan,

drie na wit en hy na bruin skool gaan.

Hierdie mineurtoon wat miskien roerender en meer dramatiese inslag het, blyk baie mooi uit een van die literêr heel geslaagde gedigte wat die saak van die swartman opneem. Ek verwys na Ingrid Jonker se gedig Die Kind waaruit 'n bewoënheid maar ook 'n subtiele geloof spreek:

Die kind is nie dood nie

die kind lig sy vuiste teen sy moeder

wat Afrika skreeu skreeu die geur

van vryheid en heide

in die lokasies van die omsingelde hart

Die kind lig sy vuiste teen sy vader

in die optog van die generasies

wat Afrika skreeu skreeu die geur

van geregtigheid en bloed

in die strate van sy gewapende trots

Die kind is nie dood nie

nòg by Langa nòg by Nyanga

nóg by Orlando nòg by Sharpeville

nòg by die polisiestasie in Philippi

waar hy lê met 'n koeël deur sy kop 
Die kind is die skaduwee van die soldate op wag met gewere sarasene en knuppels die kind is teenwoordig by alle vergaderings en wetgewings die kind loer die vensters van huise en in die harte van moeders

die kind wat net wou speel in die son by Nyanga is orals die kind wat 'n man geword het trek deur die ganse Afrika die kind wat 'n reus geword het reis deur die hele wêreld

Sonder 'n pas.

\section{(ROOK EN OKER)}

Sulke woordkuns soos hierdie sou ek engagée noem: dit het 'n duidelike omlynde doel, saak, ideaal voor oë, sonder om in blote plakkaatpropaganda te ontaard. Soos ek elders aangetoon het (DIE SESTIGERS, Verslag oor 'n simposium; Human en Rousseau, Kaapstad, 1973: „Die prosa van die Sestigers"), is dit juis myns insiens een van die tekortkominge van die Sestigerprosa, naamlik dat dit hom te veel besig gehou het met die mens as abstraksie en die konkrete SuidAfrikaanse situasie romanmatig onbenut gelaat het. Dit is omdat die Sestigerromankuns te simbolies, allegories te werk gaan en omdat die skrywers te behep is met lewensfilosofiese sake. Vergelyk in hierdie opsig Leroux wie se sentrale tema is die desintegrasie van die moderne mens se mites (geloof) en simbole.

Weens sy onvermydelike konkretiserende aard van die kuns kom die Suid-Afrikaanse werklikheid ter sprake in dié boeke, is daar selfs heelwat kritiek (soos in Brink se Die ambassadeur) of satire (vgl Etienne Leroux Die derde oog die materialisme en sekularisme), maar werklike engagement is daar skaars, al het daar ook sedert F A Venter se Swart Pelgrim en Rabie se Ons die afgod werke verskyn wat die tema van die "rasseprobleem" aansny: Barnard: Man in die middel, W A de Klerk: Die laer, ens. 'n Mens het verwag dat Leroux se $N a^{\prime} v a$ hierdie onderwerp sal aandurf, maar dis wesenlik 'n ander swart wat hier aan bod kom. Werklike engagement soos ons dit kry in Bartho Smit se kortverhaal: $E k$ vat $m y$ land is skaars. Hier gaan dit om 'n Bantoeskilder wat sy land, soos hy dit stel, van die witman terugneem deur dit op besondere wyse op die doek vas te lê. 
Weer eens 'n strewe, 'n aanklag, en ook 'n eensydige standpunt, iets anders as byvoorbeeld Elsa Joubert se objektiewe en panoramiese siening van die wit-swart-konfrontasie in sy Afrikakonteks (Ons wag op die kaptein, Bonga). Maar dit is wat literêre engagement veronderstel, resloos kant kies, 'n kruistog onderneem, ' $n$ soort blinde niksontsiende geloof in 'n saak, 'n strewe, ' $n$ ideaal. Iets van hierdie engagement ten opsigte van ' $n$ ander lewensfaset, die religieuse, kry 'n mens by Berta Smit, onkompromitterend reformatories: uitverkiesing, wedergeboorte, heiligmaking - die mens as koning, priester en profeet onvoorwaardelik in diens van God maar dan in sy konkrete verhouding tot die medemens en die aardse werklikheid.

Miskien is die epiese medium nie ideaal vir engagement nie en is dit daarom dat juis dié skrywers wat die drama beproef, ook die naaste aan my opvatting van litterature engagée kom: Adam Small en André P Brink. Eersgenoemde se gedigte het reeds ter sprake gekom, maar daar is ook nog sy sosiale drama, Kanna hy kô hystoe. Brink demonstreer die mutasie van die verhoogstuk tot betoogstuk in Die verhoor en Die rebelle waarin hy historiese stof (Slagtersnek) 'n onmiskenbare hedendaagse aktualiteitskinkel gee.

Brink bied dus sy eie dramatiese interpretasie aan sy stof, skryf in Die verhoor voort aan die algemene tema van sy vernaamste werke. En dit is die vrye mens, of dan hierdie skrywer se siening van die moderne mite van die vrye mens - die mens wat hom wil vry maak van alle bande van konvensie en gesag, sy eie wet en wetgewer wil wees, slegs een gesag erken, en dit is die voorskrif van sy private gewete. Hier is Frederik Bezuidenhout in 'n politieke en sosiale sin 'n Brink-beliggaming van dié strewe. Ten opsigte van dramatiese oortuigingskrag en literêre geldigheid skiet die stuk egter tekort, soos ook die vervolg: Die rebelle.

Dié word deur die skrywer self gekwalifiseer as 'n betoogstuk; dus 'n drama van 'n besondere aard en strekking: die tema is "stryd teen die owerheid", soos die hoofkarakter dit formuleer (bl 32). Dis ' $n$ owerheid, volgens die woorde van hierdie rebelle soos herskep deur Brink, wat menslike waardigheid en vryheid aantas, wat sy ,aparthede" op sy onderdane afdwing. Weer eens dus 'n drama met 'n dubbele bodem en ' $n$ bydrae tot die sogenaamde literatuur van die 
verset.

Afgesien van 'n tegniese vindingrykheid of wat, skiet Brink se dramatiese herskepping van die rebelliegeskiedenis as sodanig tekort. En omdat die dramatiese realiteit ontoereikend is, is ook die pogings om die stukke 'n hedendaagse toepaslikheid te gee nie besonder geslaagd of het dit grootse impak nie. Dit bly maar alles woorde, woorde, myns insiens nie ontdaan van humanistiese retoriek nie. Die betoog is nie dramaties stewig genoeg gefundeer nie.

Met vollediger betrokkenheid nog as in sy dramas durf Brink die tema van kleurproblematiek aan in sy jongste roman: Kennis van die aand, en bevestig so sy uitspraak dat Sewentig ' $n$ deurbraak moet bring na die sosiaal-politieke vlak en die rasseprobleem, want Sestig was syns insiens nooit engagé genoeg nie. Deur die oë en ervaring van die hoogs ontwikkelde, sensitiewe en begaafde toneelspeler en regisseur, die Kleurling Josef Malan, verken die roman dan die breedte en diepte van hierdie situasie: dié van die Bruinman in 'n Blank beheerde maatskappy. Josef verenig in hom die bloed van alle rasse in Suid-Afrika, beoefen die "teater van die verset", met ander woorde herinterpreteer bekende dramas tot 'n protes teen apartheid, beoefen liefde oor die kleurgrens en word deur wanhoop, nà vervolging en stryd, gedryf tot moord en ondergaan marteling deur die veiligheidspolisie. Dis 'n sterk en omvangryke gegewe wat Brink hier romanmatig benut, dit gee 'n panoramiese blik op die toestande, is vaardig en skerpsinnig en virtuoos verwoord. Maar as roman, veral as kritiekroman, engagé-roman, slaag die werk skaars. Daarvoor is die hele inkleding te boekerig, is daar te veel herkenningselemente uit Brink se bestaande oeuvre, is die belewing te subjektief eensydig en dikwels onoortuigend stereotiep. Nietemin is dit ' $n$ moedige roman, bring dit 'n sterk blik op die mense van die ,aand", dit wil sê die Kleurlinge en hulle lot, maar die hele beeld mis die grootsheid en intensiteit om 'n visie te gee van 'n ontdekkende ,kennis van die aand", soos Sint Jan van die Kruis dit wou hê, naamlik essensiële menslikheid. Subjektivisme, en 'n sekere oordaad, 'n te veel, onder meer van die seksuele ervaringe, laat die roman sy doel verbysteek. Desondanks is dit, veral om sy onverskrokkenheid en genuanseerdheid, ' $n$ beduidende toevoeging tot die register van die romans wat oor kleur en politiek handel. 
Dit is eweneens literatuur van die verset hierdie, maar Brink is kunstenaar genoeg om dramaties-beeldend te werk te gaan en nie betogend te propageer nie. Die hele denkklimaat, die hele karakter van die roman sluit egter, bewus of onbewus, sterk aan by die rewolusiegedagtes van Herbert Marcuse ( $\mathrm{vgl}$ die rol wat hy toeken aan die kunstenaar, die intellektueel in die verwesenliking van die kulturele rewolusie). Die ideaal vir Marcuse is die volstrek outonome, vererotiseerde en normlose mens - normloos dan wel so te verstaan: volkome individuele vryheid; die mens is sy eie wetgewer en gesag. Hierdie Josef Malan van Kennis van die aand is 'n konkretisering van Herbert Marcuse se ideale mens.

Maar die intensiteit van $\mathrm{Na}$ die geliefde land deur Karel Schoeman het Brink se werk nie. Ook nie die aangrypendheid nie, hoewel (miskien: omdat) Schoeman veel meer van die tegniek van onderbeklemtoning en suggestie gebruik maak in sy politieke roman. Weliswaar nie kleur-politiek nie, maar Afrikaner-politiek, hoewel 'n mens nie aan die indruk kan ontkom nie dat die periode van post-Afrikanerheerskappy waarteen die gebeure afspeel, byvoorbeeld die brutale optrede van die polisie, dit Nieblankes is wat in beheer van sake is.

$\mathrm{Na}$ die geliefde land is 'n ongewone variasie van die toekomsroman. Die hooffiguur is op 'n vlugtige besoek aan SuidAfrika, jare nadat daar ' $n$ magsomkeer was en die meeste invloedryke Afrikaners uit die land moes vlug. Hy self het in Europa groot geword, kom kyk nou na die ou verwaarloosde familieplaas. Tydens sy verblyf by ' $n$ boeregesin maak hy kennis met hulle drome van 'n vergane glorie, èn met die wreedheid van die nuwe terreur. Alle vorme van Afrikanerverset word genadeloos onderdruk, en die enigste uitweë is vae hunkering na die verlede of aanvaarding van en aanpassing by die nuwe omstandighede. Dit is 'n suggestieryke en diep gevoelige beeld van die herfsty en komende winter van die eens hoogbloeiende Afrikanerkultuur en hegomonie - objektief en tog ontroerend liefdevol gebeeld, sonder aanklag, sonder verwyt, 'n prosa-elegie van hoë estetiese kwaliteit en daarom betekenisvol en treffend. Hier het ons 'n uitgesprokener romanmatige handgemeen raak met die politieke werklikheid as die geïmpliseerde bybetekenis van Schoeman se Ierse historiese roman, By fakkellig.

Literêre engagement is ' $n$ geskakeerde en ook dinamiese 
begrip. In die sin waarin dit vandag meestal verstaan word, naamlik 'n intense, protesterende betrokkenheid by die status quo op veral sosiaal-politieke gebied, met die onlosmaaklike vervlegting van die verset met die volkereverhoudingsvraagstuk, is daar dus deur die jare 'n grondslag gelê en in die jongste dekade of wat sterk pogings aangewend om ons literatuur ook verbonde of betrokke te maak. Of dit die hoofkoers van die letterkunde in die jare sewentig gaan word, moet ons afwag om te sien, maar aangesien die membraan tussen die lewe van die alledaagse aktualiteit en die woordkuns dun is, kan ons 'n toenemende osmotiese beïnvloeding van die letterkundige vanuit die politiek-sosiale noodsaak en dwang verwag. 


\section{DIE VRYHEID VAN DIE SKRYWER}

In DIE BURGER van 10 Januarie 1974 (dus in 'n tyd waarin die vryheid van die woordkunstenaar sterk onder die soeklig kom in die pers) word daar 'n stuk uit THE CAPE TIMES oorgedruk wat handel oor die Russiese skrywer Alexander Solzhenitzyn. Dit begin met die woord moed: die moed van Alexander Solzhenitzyn te midde van die ondraaglikste amptelike vervolging en druk dwing ons bewondering af, noop ons in die Weste om hom morele ondersteuning te gee. Sterk affektiewe taal, soos trouens die hele trant van die stuk emosioneel gelaai is.

Solzhenitzyn sou 'n paar maande gelede verklaar het dat sy lewe bedreig word, dat indien hy skielik omkom, die KGB (Geheime Polisie) aandadig sou wees. Sedertdien het hy in Parys 'n boek in Russies gepubliseer wat handel oor die strafkampe (gedwonge arbeid). Uit ander bronne weet ek die manuskrip is uitgesmokkel omdat dit in Rusland onaanvaarbaar (verbode) is. Uittreksels is reeds in Engels vertaal, en die titel wat die CAPE TIMES-artikel aangee, is GULAG ARCHIPELAGO. Die skrywer self was jare lank tot dwangarbeid in so 'n kamp veroordeel. Vergelyk maar die Afrikaanse vertaling van sy roman DIE DAG VAN IVAN DENISOWITSJ.

Die artikel gaan voort en wys daarop dat die amptelike Sowjet-nuusagentskap Tass hierdie publikasie fel veroordeel en die Nobelpryswenner (maar Solzhenitzyn het nooit sy prys gaan haal nie, weet ons, want daardeur sou hy hertoelating tot sy geliefde vaderland verbeur) daarvan beskuldig dat hy sy land en sy volk haat. Die artikel sê dis 'n ironiese aanklag, want Solzhenitzyn is 'n uitmuntende patriot.

Dan volg die kernargument van die artikel, en die beginsel waarop ek die aandag wil vestig. 'n Groep Russiese intellektuele het hulle aan Solzhenitzyn se kant geskaar en die reg bevestig van 'n mens om te skryf en te publiseer wat sy gewete dikteer. Die res van die stuk is 'n oproep om steun vir hierdie dapper en briljante man, en ook 'n waarskuwing aan belangrike figure buite Rusland om met nederigheid na hulle eie gemeenskappe te kyk en hulle af te vra of daar onder hulle ook skrywers is wat amptelik die swye opgelê, gesensureer of lastige geval is. In baie sogenaamde vry lande bestaan 
hierdie basiese reg van 'n beskaafde gemeenskap nie, naamlik om te publiseer wat die gewete voorskryf. Hierdie basiese reg is in sulke gemeenskappe omskrewe (begrens) of bedreig en moet hoog gehou word. Aldus die CAPE TIMES-artikel.

Dit gaan dus hier om die vryheid van siening en segging en publikasie van die skrywer as waarde, en die beginsel waarop hierdie vryheid berus, is die voorskrif van die skrywer se gewete. Dit klink alles baie mooi en menslik en edel - is inderdaad ook ' $n$ volkome humanistiese en idealistiese siening van die saak. Vryheid, ook van die skrywer, is bepaald iets wat ons almal hoog op prys stel, maar om jou vir daardie vryheid te beroep op die menslike gewete, is, om dit sagkens te stel, naïef. Die menslike gewete is feilbaar, is bowendien iets wat ontwikkel, wat gekondisioneer word, selfs onklaar raak. Dit kan, selfs nie in die uitnemendste onder die mense nie, 'n volkome betroubare maatstaf vir wat waar, goed of reg is, wees nie.

Laat ons aanneem dat Alexander Solzhenitzyn 'n betroubare beeld gee van die strafkampe of arbeidskampe. Ek het slegs DIE DAG VAN IVAN DENISOWITSJ gelees en kan nie oor die Paryse publikasie oordeel nie. Maar die boek wat ek ken, gee 'n ontroerende visie op die mens onder moeilike omstandighede, eerder as wat dit 'n blatante aanklag teen 'n stelsel is. En daarom is die aanklag des te geldiger, juis omdat dit ewewigtig, subtiel, met deemoed en in terme van menslike lyde en moed en heroïek geskied. Hoe objektief, hoe getrou die voorstelling van die kampe ook al mag wees, dit bly nog altyd een mens se siening en aanbieding en interpretasie van feite. Daar is dus ook subjektiewe elemente by. Dit is sekerlik nie die enigste of volledige waarheid nie, Nie dat die Kremlin of wie ook se beeld die waarheid sou bevat nie, maar miskien sit daar tog 'n waarheidsmoment in die burokraat of diktator se interpretasie.

Maar goed, ons aanvaar dat Solzhenitzyn 'n lewensgetroue beeld gee, sy dit dan sy eie, van die kampe, en omdat dit so lewensgetrou is, is dit onaanvaarbaar vir die politici wat die kampe of misbruik of dit met hulle eie politieke dialektiek vergoeilik. Maar dan nog is Solzhenitzyn se beeld nie lewensgetrou òmdat dit gewetensgetrou is nie. Hy beeld nie die waarheid kragtens sy gewetensvoorskrif nie, maar kragtens sy talent as woordkunstenaar: sy ingeskape vermoë en sy ont- 
wikkelde tegniek om die woord te hanteer en die lewe te beeld en die waarheid te peil. Was dit nie vir hierdie gawe van kunstenaarskap nie, kon sy gewete hom maar hoe gedwing het, kon hy ook watter vryheid gehad het, maar 'n egte woordwêreld sou hy nie kon skep nie. Solzhenitzyn se gewete is net so feilbaar soos enige mens s'n. Dis sy kunstenaarskap wat sy gewete puur, of dan sy gewete so rig dat hy na aan die waarheid uitkom in sy werk.

Solzhenitzyn is 'n groot en begenadigde maar gecnsins volmaakte kunstenaar nie, en ons moet aanvaar dat ook sy werk nie die volledige waarheid uitdruk in verband met die onderwerpe of temas waaroor hy skryf nie.

Maar die drogredenasie is nou om Solzhenitzyns oral te soek en te vind, dié skrywers wat 'n sogenaamde onderdrukte bestaan voer omdat hulle nie volledig aan die voorskrifte van hulle gewetes uitdrukking kan gee nie. En wanneer so 'n skrywer 'n aantoonbaar subjektiewe beeld van toestande in sy eie land gee, die subjekticwe te ignoreer en sy dikwels sterk gekleurde beeld aan te dien as die waarheid.

Nee, 'n norm om te gebruik, sou eerder die Bybelse maatstaf van die waarheid wees: jy mag geen valse getuienis gee nie. Want hierdie soort literatuur getuig altyd, en sy getuienis verwys na buite; daarom is die toetssteen vir sy waarheid dan ook die werklikheid waarna dit verwys en waaroor dit getuig.

Natuurlik lewer alle soorte literatuur in 'n sekere mate getuienis, maar dit gaan nie nou om individualistiese of romantiese letterkunde wat van die ek en sy private binnewêreld spreek nie; wel om verbonde of betrokke literatuur, die sogenaamde litterature engagée wat spesifiek 'n saak, 'n ideaal bepleit of wil bevorder, die lot van 'n groep, 'n gemeenskap, 'n volk wil verbeter, verander - woordkuns op 'n kruisvaart teen onreg of vermeende onreg op sosiaal-ekonomies-politieke gebied, 'n stryd teen 'n bestaande orde. Dié soort woordkuns het 'n sterk gemeenskapsinslag, is strydliteratuur, al werk dit ook, soos die wyse van die woordkuns is, met die konkrete enkeling en die besondere situasie. Maar daardie literatuurgestaltes en situasies en gebeure word altyd, implisiet of eksplisiet, voorgehou as tipies van 'n bepaalde heersende toestand.

Die waarheid of onwaarheid van die beeld wat die werk 
oproep of skep, het blykbaar min te doen met die kwaliteit van die boek. So kan daar, suiwer as kuns van die woord beoordeel, goeie poësie wees, maar die stelling wat dit maak, is onwaar, of dan op sy meeste nie die volle waarheid nie, byvoorbeeld 'n gedig wat onder meer praat van

„ons mistasting na mens-wees

omdat ons God wou wit maak

en wit God."

Dit is die onvermydelike noodlot van hierdie soort betogende, strydvaardige verbonde literatuur: dit is eensydig, selfs oordrewe. Ek weet maar al te goed dat alle letterkunde dramaties-beeldend te werk gaan, dat daar 'n seleksie, ordening en selfs oorbeklemtoning van die boustof is, 'n persoonlike visie en aanbod. Dit ter wille van die suggestieryke konkretisering van die tema, die idee, ter wille van die appèl, die slaankrag, die ontroeringsvermoë. Maar omdat litterature engagée juis 'n saak stel, 'n hervorming wil bewerkstellig, daarom maak dit meer as dikwels die pap so dik aan dat geen keel dit kan sluk nie. Behalwe daardie kele wat deur nog harder skree vir daardie saak uit gewoonte of bygeloof uit lit gerek is.

Dis ' $n$ subjektiewe beeld, die weergawe van 'n siening van sake soos gedikteer of gedring deur die persoonlike gewete. Maar is dit die waarheid, die volle waarheid en niks minder of meer as die reine waarheid nie? Daar mag geredeneer word dis poëtiese of literêre waarheid, omdat dit geslaagde woordkuns is, maar juis daarom is die woordkunstenaar geroepe om dubbel versigtig sy vryheid en verantwoordelikheid te hanteer.

Die illusie van waarheid, van gewone alledaagse waarheid te wees, is veel sterker in die roman - veral die soort roman wat hom aandien as die verslag van 'n lewe en lot. Nou kan so 'n verhaal wel vaardig en selfs onderhoudend geskryf wees, vol patos: 'n deerniswekkende relaas van 'n begaafde gekleurde man se lyde en sterwe in ' $n$ blank beheerde samelewing en dié se wrede stelsel. 'n Populêre roman in die beste tradisie van Konsalik. Naderby beskou wesenlik baie oppervlakkig. literêr swak, polities vals, eties voos en godsdienstig afwysend.

Literêr swak weens die oordaad, die herhaling, die stereotiepe, die vlakheid, al die tweedehandse boekerigheid. Polities 
vals weens die eensydige en oordrewe beeld van die ongeregtigheid, die vervolging, die marteling. Eties voos weens die oordadige seksualiteit, die tekening van die mens as 'n volkome vererotiseerde wese wat opgaan in die vrye liefde. Godsdienstig afwysend teenoor God: Vader, Seun en Heilige Gees. Die verheerliking van die godsdienstig outonome mens. Dus in totaal die verwesenliking van Marcuse se vrye vererotiseerde, rewolusionêre, ontvoogde mens.

Natuurlik is dit die skrywer se reg om sake so te sien en uit te beeld. Ek gun hom van harte die vryheid om dit in druk te laat verskyn, mits hy en ek en elke leser maar besef dis nie by benadering die volle waarheid nie - die waarheid wat die toets van die werklikheid waarheen dit uitwys, kan deurstaan. Hierdie skrywer moet besef, besef dit dalk maar juis al te goed, dat sulke soort skryfkuns nie middelpuntsoekend is soos byvoorbeeld die poësie van Elisabeth Eybers nie. Dit gaan nie om 'n subjektiewe waarheid van die ek se belewenis nie; dit is middelpuntvliedend, reik uit na buite, wil die buitewerklikheid beeld en die buitewêreld beïnvloed.

Solzhenitzyn kan maar tot die hele wêreld spreek en sy siening van die Russiese politieke stelsel en alles wat daarmee saamhang, as die waarheid voorhou. Hoeveel reg hy ook aan sy kant het, en veral indien wel, hy is gedoem tot tragiese mislukking. Niks kan die reusagtige Russiese beer deer nie: hy is groot en sterk en onaantasbaar.

Maar die Suid-Afrikaanse situasie is anders. Die springbok is broos en klein en kwesbaar - die roofdiere lê op die loer, grom reeds, val al aan. En laat niemand homself mislei nie. Of die premier van Suid-Afrika, en alles wat dit impliseer, nou Vorster is of Graaff, Eglin of Schwartz, Buthelezi of Matanzima of Mangope of Leon of wie ook, die grense van ons land sal met wapens verdedig moet word teen die invallers. Want dit gaan nie om 'n poging om die sogenaamde blanke heerskappy te beëindig nie - die universeel gerigte ideologiese rewolusie omvat veel meer as dit, en sal, soos Koki van Raka voorspel het, „heers oor ons, en groot en lang pyn bring" indien dit sou slaag. Daardie ons is alle SuidAfrikaners, ongeag kleur.

Daarom sê ek moet die skrywer sy vryheid om die aandrang van sy gewete te volg en sy persoonlike siening van sake sterk en meesleurend te verwoord, met omsigtigheid en ver- 
antwoordelikheid hanteer. Die pen wat hy hanteer, is dalk werklik magtiger as die swaard.

Ek wil pleit daarvoor dat sulke "gevaarlike" werke in Afrikaans nie verban word nie, want dit sou maar net die tuisverbruik raak. En dis juis in vertaalde vorm dat dié werke vir opsweping, agitasie, as motivering van die aanvallers met woord en wapen gebruik en misbruik kan word. En verban $\mathrm{jy}$, is die kans vir opsweping soveel sterker.

Nee, laat ons wat immers saam met die skrywer 'n vergelykingsbasis van gedeelde ervaring en kennis van die SuidAfrikaanse toestande het, die dinge lees. Maar laat ons nie daaroor swyg nie. Laat ons dit uitpraat met mekaar: skrywer, literator, leser. Met ander woorde: as die skrywer dink of voorgee dat hy vir die waarheid getuig, gun hom sy vryheid. Maar laat elkeen wat ook van die saak kennis dra, ook getuig, soos hy die waarheid sien en wil dien, byvoorbeeld deur die tekortkominge van die boek bloot te lê, ook ten opsigte van wat waar is. Maar laat ons onthou dat die norm van waarheid nie ons gewete of visie is nie, maar wel dat ons geen valse getuienis teen ons naaste mag spreek nie. Ook nie literêr of kwasi-literêr of krities nie. So kan ons as lesers die dalk goed bedoelde maar verblinde skrywer se visie herstel of skerper instel, hom meer bewus maak van sy verantwoordelikheid. So alleen kan ons mede-arbeiders van die waarheid word, soos die apostel Johannes in sy derde brief aan Gajus skryf. En die waarheid in liefde aangewend, is 'n magtige wapen teen en remedie vir sonde en menslike onvolkomenheid. 